\title{
EDITORIAL
}

\section{Oliver Sacks and his legacy to vision science and ophthalmology}

\section{Oliver Sacks e o seu legado para a ciência da visão e a oftalmologia}

\author{
Eduardo Melani Rocha ${ }^{1}$, Luiza Aikawa da Silveira Rocha ${ }^{1}$, Galton Carvalho Vasconcelos ${ }^{2}$, Monica Alves ${ }^{3}$
}

A little boy enchanted by chemistry and the periodic table elements, a motorcycle young man who crossed a continental country in so many directions, scuba diver and olympic weightlifter, an obsessive researcher and a dedicated physician. These are some facets of a brilliant human being. Oliver Wolf Sacks was born in London in July 9, 1933, graduated in Medicine at Oxford University, England, specialized in Neurology in California, USA, and worked most of his life in New York City, USA ${ }^{(1)}$. The reason to bring him to an editorial in ABO (Arquivos Brasileiros de Oftalmologia), a journal dedicated to vision and ophthalmology, is because early in his professional career he became a writer, describing neurological patients, with particular and talented reports on ocular conditions, visual symptoms and neuro-ophthalmologic correlations in his writings.

Talented clinicians are becoming rare, talented clinicians with writing talent are even more so. Dr. Oliver Sacks must be known by the present and future generations of physicians as a writer that wrote in a way that allowed the reader to know about the disease, but, more importantly, to know how the patient felt and dealt with his condition, through poetic lines of his numerous books and articles

He became a bestselling and awarded author all over the world, with writings that gave voice, face and action to patients with chronic, sometimes uncommon, and severe diseases. He published 14 books and authored or co-authored 58 papers. So far, 14 of his writings became documentaries and three of his tales, including the famous "Awakenings" inspired films ${ }^{(2)}$.

Overall, he taught the physicians to consider the patient's perspective in the first place. In his recent published autobiography "On the Move: a life", he revealed that his style was inspired by medical writers of the XIX century ${ }^{(3)}$. This influence was clear in references used in his books, in particular in "An Anthropologist on Mars", where in seven dramatic stories, he revealed his deep sensitivity to the vision complaints of his patients. The first case described the suffering of a painter who became color blind after a car accident. The fourth case described a middle age individual who experienced to see again after decades of blindness. In the fifth and sixth cases he described patients with different conditions that had in common an intense visual memory and capacity to draw these views. All of those reports were fulfilled with beautiful wording and illustrations, as well as detailed local descriptions and medical references, dating back to the beginning of the XVIII century ${ }^{(4)}$.

Among the visual symptoms addressed in his papers were visual hallucinations, metamorphosis and visual agnosia ${ }^{(5-7)}$. These papers are strongly recommended reading, not just because of the clear and thoughtful presentation, but also because these subjects are challenging and usually neglected during medical training.

For those who read the "The Island of Colorblind" it will be always engraved on our minds the intriguing condition of a society where total congenital colorblindness is the norm, and how adaptation may occur ${ }^{(8)}$. These reflections may teach how to cope with patient fragilities face to a condition that leads to visual deficiency and how adaptation and acceptance may improve their lives.

Other books, including "Migraine", his first one, addressed the visual symptoms of this condition with a rich description and interpretation of the mechanisms, but even for those not related to the eye care, it is certainly worthwhile reading (Table 1). As he wrote in his autobiography "It seems to me that I discover my thoughts through the act of writing, in the act of writing"(3)

To understand his patients conditions profoundly he used to search their symptoms and diseases pathways. This was beautifully reflected in the many partnership he had along his career, such as Crick, Hubel, Wiesel and Edelman; Nobel laureates who were also important contributors in his works, as many other that influenced him such as Thom Gun, Luria and Auden. He showed a wonderful way to go further and a great example to be followed by researchers and clinicians.

His last book was originated by articles published in the New York Times, describing his joy with the life experience apart from his own drama fighting against an ocular melanoma, first diagnosed in 2006, which revealed metastases on January 2015(9). It was called "Gratitude" and was a posthumous publication. Sadly, Dr. Oliver Sacks died on August 30 of 2015. Based on the last words of his autobiography, it is clear that his literature legacy is not yet finished ${ }^{(3)}$.

Sumitted for publitcation: November 13, 2015

Accepted for publitcation: November 17, 2015

${ }^{1}$ Departamento de Oftalmologia, Otorrinolaringologia e Cirurgia de Cabeça e Pescoço, Faculdade de Medicina de Ribeirão Preto (FMRP), Universidade de São Paulo (USP), Ribeirão Preto, SP, Brazil. 2 Departamento de Oftalmologia e Otorrinolaringologia, Faculdade de Medicina da Universidade Federal de Minas Gerais (UFMG), Belo Horizonte, MG, Brazil.

3 Departamento de Oftalmologia e Otorrinolaringologia, Faculdade de Ciências Médicas, Universidade Estadual de Campinas (UNICAMP), Campinas, SP, Brazil.
Funding: Financial Support: CNPq, NAP-FTO USP.

Disclosure of potential conflict of interest: None of the authors have any potential conflict of interest to disclose.

Corresponding author: Eduardo Melani Rocha. Departamento de Oftalmologia, Otorrinolaringologia e Cirurgia Cabeça e Pescoço. Faculdade de Medicina de Ribeirão Preto - USP. Av. Bandeirantes, 3.900 - Ribeirão Preto, SP - 14049-900 - Brazil - E-mail: emrocha@fmrp.usp.br 


\begin{tabular}{lc} 
Table 1. Oliver Sacks books related to visual symptoms and ocular diseases \\
\hline Title & Year published \\
\hline Migraine & 1970 \\
The man who mistook his wife for a hat & 1985 \\
Seeing voices & 1989 \\
An anthropologist on Mars & 1995 \\
The island of the colorblind & 1997 \\
The mind's eye & 2010 \\
Hallucinations & 2012 \\
On the move: a life & 2015 \\
\hline
\end{tabular}

\section{REFERENCES}

1. Wikipedia: the free encyclopedia [Internet]. St. Petersburg (FL): Wikimedia Foundation; 2001. Oliver Sacks.[cited 2015 Nov 17]. Available from: https://en.wikipedia.org/ wiki/Oliver_Sacks

2. Oliver Sacks, M.D [Homepage]. [Cited 2015 Nov 15]. Available from: http://www. oliversacks.com/inspired-by-sacks/

3. Sacks OW. On the move: a life. Canada: Alfred Knopf; 2015

4. Sacks OW. An Anthropologist on mars. New York: Alfred Knopf; 1995.

5. Sacks O. Regaining binocular stereoscopic vision in adulthood. A case report. A neurologist's notebook. Stereo Sue. Why two eyes are better than one. (Reprinted with permission from The New Yorker, June 19, 2006). Binocul Vis Strabismus Q. 2006;21(3): 160-9. Comment in: Binocul Vis Strabismus Q. 2006;21(3):170.

6. Herrmann C Jr. Aguilar MJ Sacks OW. Hereditary photomyoclonus associated with diabetes mellitus, deafness, nephropathy, and cerebral dysfunction. Neurology. 1964; 14:212-21.

7. Blom JD, Sommer IE, Koops S, Sacks OW. Prosopometamorphopsia and facial hallucinations. Lancet. 2014;384(9958):1998.

8. Sacks, O. The Island of the colorblind. New York: Alfred Knopf: 1997

9. Sacks O. My own life: Oliver Sacks on learning he has terminal cancer. New York Times [Internet]. 2015 Feb 19. [Cited 2015 Nov 15]. Barczyk H. The opinion pages. Available from: http://www.nytimes.com/2015/02/19/opinion/oliver-sacks-on-learning-he-hasterminal-cancer.html?_r=

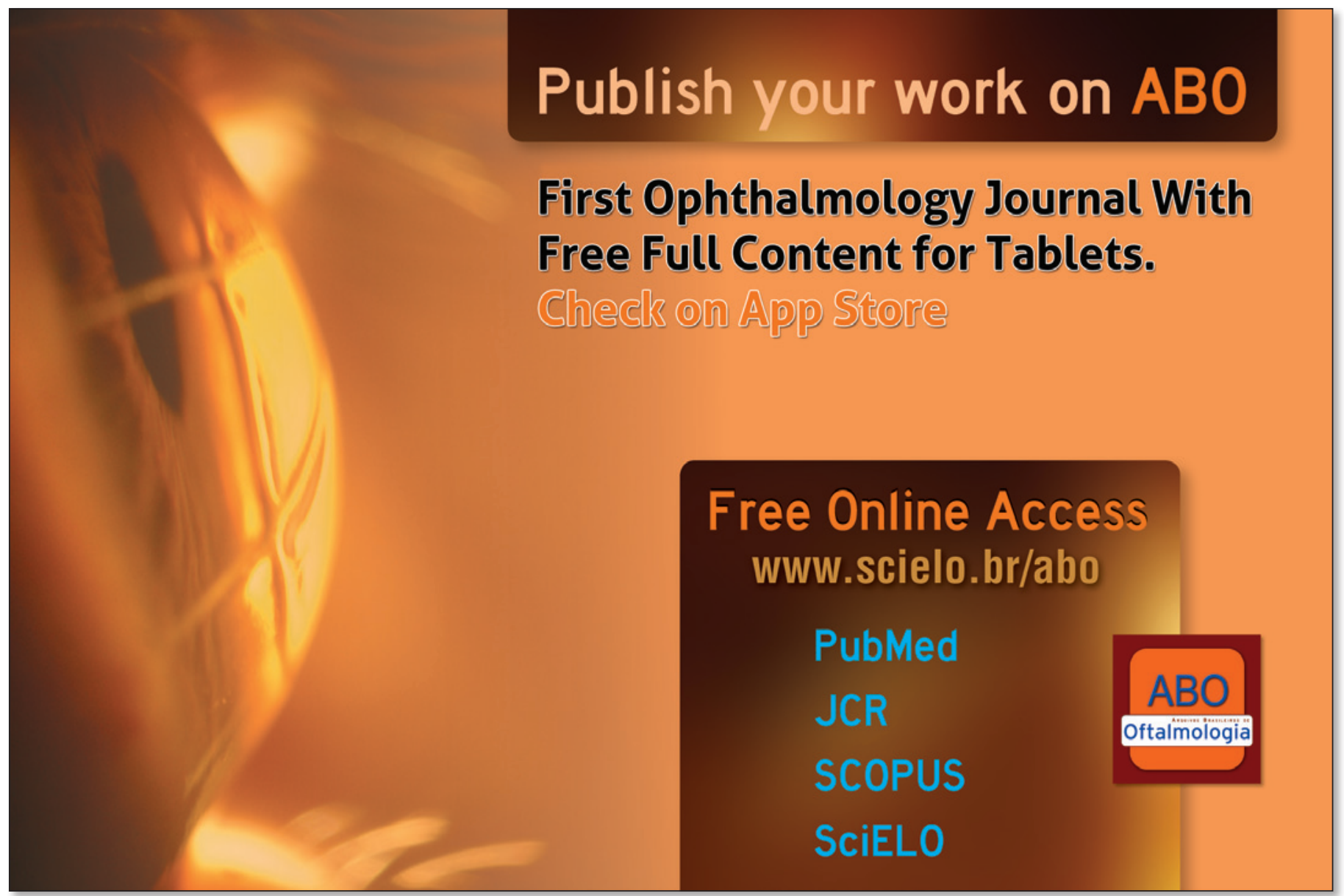

